\title{
Psychometric Properties of a Measure of Resilience Among Middle-Adolescents in a South African Setting
}

\author{
Ruth Mampane \\ Faculty of Education, University of Pretoria
}

Adress correspondence to Ruth Mampane, Faculty of Education, University of Pretoria, Aldoel Building, Room 2-53, Pretoria, South Africa, 0002. Email: ruth.mampane@up.ac.za

This study reports on the reliability of scores and the structural properties of a resilience measure used with adolescents from a low resource South African neighbourhood. The Resilience Questionnaire for Middle-Adolescents in Township Schools (R-MATS) was administered to 213 Black, Grade 9 middle-adolescent learners ( $M$ age = 14 yrs, 11 months, $S D=0.54$, girls $=38.5 \%$, boys $=61.5 \%$ ). Internal consistency measures were computed including Exploratory Factor Analysis. Four factors defined resilience in the setting: confidence and internal locus of control, social support, toughness and commitment, and achievement orientation. The R-MATS appears reliable for measuring resilience among teenagers in low-income settings.

\section{Keywords: resiliency, resilence, resilience questionnaire, middle adolescence}

Resilience demonstrated by youths and children is not purely the result of their intrinsic characteristics; it can partly be attributed to supportive contextual and normative factors that promote their healthy and positive development (Masten \& Obradovi , 2006; Werner, 1995; Werner \& Smith, 1982). Children from historically disadvantaged neighbourhoods face significant socio-cultural challenges; and their resilience is particularly important for healthy functioning. In the South African context, with its racially based disadvantages from the colonial period, many Black teenagers live with chronic psychosocial challenges.

For instance, adolescents in a low-income environment are exposed to many challenges emanating from poverty to a lack of teaching and learning resources (Christie, Butler \& Potterton, 2007; Crouch \& Mabogoane, 2001; Kamper, 2008; Masitsa, 2005). However, resilience research indicates that many youths overcome the debilitating effects of risk in their environment and develop as successful, competent and resilient individuals (Masten, 2001; Ungar, 2008; Werner \& Smith, 1982). These findings could also be true of many township youths.

Understanding the resilience factors that influence those youths in adverse conditions requires reliable measures, which are valid to make conclusions about their state of wellbeing Masten (2007) and Masten and Obradovi (2006) argue that resilience is inferred and interpreted from the behaviour of the individual in relation to the environmental circumstances to which he/she is exposed. Hence, interpreting the resilience of individuals is based on an understanding and knowledge of their development and potential for positive adaptation within their particular context. Ungar (2008) found that "aspects of resilience exert differing amounts of influence on the child's life depending on the specific culture and context in which resilience is realised" (p. 219). In a critical review of resilience research in South Africa, Theron and Theron (2011) likewise conclude that researchers frequently fail to match the antecedents of resilience to a specific context and culture.

This study aimed to validate a measure of resilience usable in low resource South African neighbourhoods.

\section{Method}

\section{Participants and Setting}

Purposive sampling was adopted, and two schools that accommodated learners from the formal and informal residential areas of a low-income community of Mamelodi east of Pretoria, in the Gauteng province of South Africa, were sampled to participate in the study. Participants were 213 learners (age range 14-16 years, boys $=131$ and girls $=82$ ). They were all Black South Africans.

\section{Instrument}

The R-MATS is a four-point Likert-type scale with two sections, $A$ and $B$. Section $A$ addresses the background of respondents in 11 statements detailing systemic and individual risk factors assumed relevant to township youths. The respondents were required to indicate the presence/absence of risk in their environment with Yes or No. Section B is a 24 item likert scale reflecting resilient behaviour, constructed from the resilience literature (e.g., Masten, 2001; Siegle, 2003; Werner \& Smith, 1982; Werner, 1995) as aligned to the working definition which was subsequently operationalised for the township context (Mampane \& Bouwer, 2006; Mampane, 2010). The R-MATS required the respondents to evaluate themselves against each statement using values of 'truth' (i.e., True all the time; True most of the time; Untrue most of the time and Untrue all the time).

\section{Procedure}

Permission to conduct research in public schools was granted by the Gauteng Department of Education (provincial) and the Tshwane South District office together with the Ethics Unit of the University of Pretoria. The school principal gave permission for the research and parents of learners gave consent by signing consent forms. The learners individually assented to participate. The R-MATS was administered in class during school hours. 


\section{Data Analysis}

Internal consistency reliability and the factor structure of the R-MATS were computed using BMDP Statistical Software. An internal consistency reliability of 0.82 (Cronbach's alpha and item-scale correlation 0.30 for all items) was observed. The data was pooled when school and gender indicated no significant difference.

\section{Results}

BMDP4M Statistical Software was used for data analysis. Section A (see Table 1) of the R-MATS presents the percentage of learners endorsing each of the contextual risk items and Section B (see Table 2), the factor structure loadings of each cluster of items with commonality. Four factors were indicated by the exploratory factor analysis, namely, (1) Confidence and internal locus of control, (2) Social Support, (3) Toughness and commitment, and (4) Achievement orientation.

The resilient middle-adolescent learners from township schools defined themselves as confident, with internal locus of control, able to identify and utilise social support, tough and committed, and achievement-oriented. Figure 1 further indicates that, the resilient learners' ability to identify and utilise protective factors resonates with their individual strengths (confidence and internal locus of control, toughness and commitment), while accessing resources is motivated and provided through social support and achievement orientation.

\section{Discussion and Conclusion}

The findings suggest that the R-MATS is an appropriate measure for middle-adolescents from a low resource background. Conclusively, the R-MATS helped the respondents to define themselves in their context, interactions and roles. While the R-MATS succeeded in the identification of resilience in middle-adolescent learners, the sample was not representative as only two schools from only one township participated in the study. A further validation of the measure is required using a representative sample (nationally) before generalisation can be inferred.

South African schools and communities are exposed to high levels of violence and crime, and children developing in such a context certainly require resilience to achieve healthy development. The resilience factors found in this study could assist in fostering resilience and mitigating risk in the township schoo environment, despite multiple stressors experienced by township middle-adolescent learners (e.g., violence and poor conflict resolution at school, a sense of being overwhelmed by multiple stressors, insufficient food and bad treatment at home, and having repeated a grade). The South African school curriculum focuses strongly on empowering learners with life skills in the Life Orientation subject. The latter includes implicit and explicit guidance on personal characteristics (confidence, internal locus of control, toughness and commitment), use of the school environment for support, and alignment with the school's achievement orientation.

Ultimately, as township learners are exposed to numerous adversities, support is needed to help them make it in their environment; and school is one of the contexts that can help them reach their future goals. School managers have the responsibility to ensure that the township school context caters effectively for the needs of all its learners. One such policy, inclusive education, makes it possible for every school to have support structures for the identification, support and referral of learners who experience learning problems. Thus, the school needs to act in a manner to support learners. With this rationale in mind, the R-MATS is able to guide schools and other practitioners who work with children on which areas of support to concentrate on.

\section{References}

Christie, P., Butler., \& Potterton, M. (2007). Report to the Minister of Education: Ministerial Committee on Schools That Work. Pretoria, South Africa: Department of Education.

Crouch, L., \& Mabogoane, T. (2001). No magic bullets, just tracer bullets: The role of learning resources, social advantage, and education management in improving the performance of South African schools. Social Dynamics, 27(1), 60-78. doi.10.1080/02533950108458704.

Kamper, G. (2008). A profile of effective leadership in some South African high-poverty schools. South African Journal of Education, 28, 1-18. http://www.sajournalofeducation. co. za/index.php/saje/article/viewFile/145/93

Mampane, M. R. (2010). The relationship between resilience and school: A case study of middle-adolescents in township schools (Unpublished doctoral thesis). Pretoria, South Africa: University of Pretoria.

Table 1

Percentage Endorsement of Risk Factors and Protective Factors from the R-MATS by Learners

\begin{tabular}{lllr}
\hline Risk Factors & $\%$ & Protective Factors & $\%$ \\
\hline 1. Everybody in household is unemployed & 24 & At least one in household is employed & 76 \\
2. No formal housing structure & 49 & Formal housing, brick house & 51 \\
3. Orphan one/both parents deceased & 14 & Both parents alive & 86 \\
4. Fights a lot at school - & 94 & Not involved in fights - & 6 \\
$\quad$ poor problem-solving skills & & good problem-solving skills & 77 \\
5. Insufficient food & 23 & Sufficient food & 16 \\
6. Many stressors & 84 & Few stressors & 8 \\
7. Abused at home & 92 & Feels protected not abused & 78 \\
8. Not living with parents & 22 & Lives with parents & 15 \\
9. Bad treatment at home & 85 & Good treatment at home & 90 \\
10. Bad life experiences & 10 & Good life experiences & 23 \\
11. Repeated a grade - academic problems & 77 & Adequate academic progress &
\end{tabular}


Table 2

Rotated Factor Loadings of R-MATS

\begin{tabular}{|c|c|c|c|c|c|}
\hline \multirow{2}{*}{\multicolumn{2}{|c|}{ No. Item }} & \multicolumn{4}{|c|}{ Factor Structure of the R-MATS } \\
\hline & & $1^{*}$ & $2^{\star \star}$ & $3^{\star \star *}$ & $4^{\star * \star *}$ \\
\hline 1 & I have an adult to talk to at home, who listens to me & 0.232 & 0.269 & 0.069 & -0.002 \\
\hline 2 & I make sure that I do my classwork and homework & 0.141 & 0.063 & 0.152 & 0.395 \\
\hline 3 & I do my best to find the right answer to a problem & 0.094 & 0.223 & 0.236 & -0.060 \\
\hline 4 & My teacher works hard to help me understand my work better & 0.239 & 0.011 & 0.038 & 0.142 \\
\hline 5 & I am in control of what happens to me & 0.442 & -0.056 & 0.224 & -0.449 \\
\hline 6 & I feel safe and loved at home, they want to know if I am OK & 0.139 & 0.062 & -0.022 & 0.453 \\
\hline 7 & Doing well at school is very important to me & 0.184 & -0.005 & 0.205 & 0.455 \\
\hline 8 & My future and success depend on my hard work & 0.311 & 0.030 & 0.162 & 0.174 \\
\hline 9 & I believe that I have good talents & 0.613 & -0.006 & -0.113 & -0.124 \\
\hline 10 & I do not allow people to stop me from trying to do my best in my work & 0.339 & 0.041 & 0.122 & -0.025 \\
\hline 11 & I believe that I am able to do better & 0.587 & 0.098 & 0.012 & 0.167 \\
\hline 12 & $\begin{array}{l}\text { Even when my problems are just too much, I do not give up trying } \\
\text { to make it work }\end{array}$ & 0.025 & 0.217 & 0.442 & -0.175 \\
\hline 13 & I know someone at school who cares about me and I can talk to & 0.133 & 0.434 & -0.042 & -0.003 \\
\hline 14 & I use different ways to work out a difficult problem. & 0.093 & 0.269 & 0.130 & -0.046 \\
\hline 15 & $\begin{array}{l}\text { There is at least one teacher I can talk to who listens to me and } \\
\text { encourages me to do my best }\end{array}$ & -0.221 & 1.066 & -0.084 & 0.155 \\
\hline 16 & I believe that one day things will be better for me & 0.638 & -0.054 & -0.026 & 0.164 \\
\hline 17 & I do not like to be absent from school, I hate to miss the teaching & 0.029 & 0.101 & 0.388 & 0.085 \\
\hline 18 & I know a good person whose behaviour is an example to me & 0.457 & 0.021 & 0.019 & 0.054 \\
\hline 19 & Even when I do not understand in class I don't give up trying & -0.134 & -0.095 & 0.687 & 0.119 \\
\hline 20 & My teachers made me see that I am good with my work and can do well in class & 0.485 & 0.068 & -0.011 & 0.142 \\
\hline 21 & My teachers support me to aim high and to think of my bright future & 0.149 & 0.052 & 0.241 & 0.375 \\
\hline 22 & Teachers explain a lot in class, they give extra examples & 0.225 & 0.082 & 0.050 & -0.004 \\
\hline 23 & My future is in my hands, nobody can take that away from me & 0.242 & 0.146 & -0.029 & 0.033 \\
\hline 24 & I am a tough person & 0.018 & -0.036 & 0.383 & -0.002 \\
\hline Vari & iance explained by the factor & 2.397 & 1.650 & 1.284 & 1.137 \\
\hline
\end{tabular}

Note. $1^{\star}$ : Confidence and internal locus of control; $2^{\star \star}$ : Social Support; $3^{\star \star \star}$ : Toughness and commitment; $4^{\star \star \star \star}$ : Achievement orientation; Items that loaded strongly $(\geq .30)$ on a factor are indicated in bold.

Mampane, R., \& Bouwer, C. (2011). The influence of township schools on the resilience of their learners. South African Journal of Education, 31(1), 114-126. Retrieved from http://www. sajournalofeducation.co.za/index.php/saje/article/viewFile/ 408/229

Mampane, R., \& Bouwer, C. (2006). Identifying resilient and non-resilient middle-adolescents in a formerly black-only urban school. South African Journal of Education, 26(3), 443456. Retrieved from http://www.ajol.info/index.php/ saje/article/view/25081/2075

Masitsa, M. G. (2005). The principal's role in restoring a learning culture in township secondary schools. Africa Education Review, 2(2), 205-220. doi:10.1080/18146620508566301

Masten, A. S. (2001). Ordinary magic: Resilience processes in development. American Psychologist, 56(3), 227-238. doi:10.1037/ 0003-066X.56.3.227

Masten, A. S. (2007). Resilience in developing systems: Progress and promise as the fourth wave rises. Development and Psychopathology, 19, 921-930. doi: 10.1017/ S0954579407000442
Masten A. S., \& Obradovi , J. (2006). Competence and resilience in development. Annals of the New York Academy of Sciences, 1094, 13-27. doi: 10.1196/annals.1376.003

Siegle, D. (2003). A Pre-Type III assessment survey. Retrieved from the University of Connecticut's website, http://www. delsiegle.com/

Theron, L. C., \& Theron, A. M. C. (2011). A critical review of studies of South African youth resilience 1990-2008. South African Journal of Science, 106(7/8), 1-8. doi: 10.4102/ sajs.v106i7/8.252

Ungar, M. (2008). Resilience across cultures. British Journal of Social Work, 38, 218-235. doi: 10.1093/bjsw/bcl343

Werner, E. E. (1995). Resilience in development. Current Directions in Psychological Science, 4, 81-85. Retrieved from http://www.jstor.org/stable/20182335

Werner, E. E., \& Smith, R. S. (1982). Vulnerable but invincible: A longitudinal study of resilient children and youth. New York, NY: McGraw-Hill. 


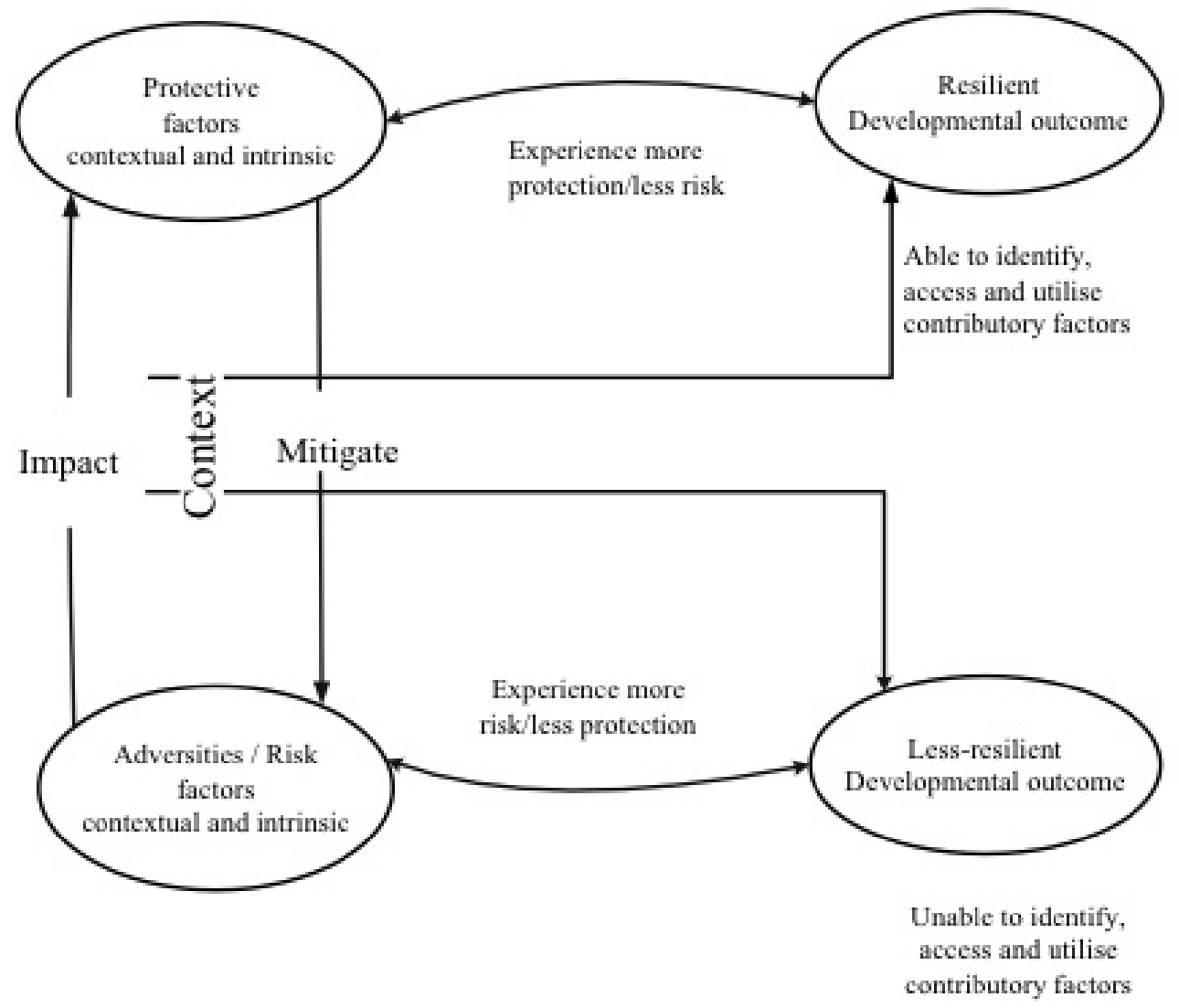

Figure 1. Resilience factors and developmental outcome

\section{Author Notes}

I gratefully acknowledge financial support from SANPAD, academic mentoring by Prof. A. C. Bouwer (University of Pretoria) and advice and assistance with statistical data analysis rendered by Mss J. Sommerville and N. Strydom (Department of Statistics, University of Pretoria). 